\title{
The Study on the Performance of Beef Cattle Farmer Groups as an Economic Institution in Indonesia: Based on the Communication Networks
}

\author{
DYAH GANDASARI ${ }^{1}$, MOCHAMAD SUGIARTO ${ }^{2}$, DIENA DWIDIENAWATI ${ }^{3}$, \\ SARWITITI SARWOPRASODJO ${ }^{4}$, DAVID TJAHJANA ${ }^{5}$ \\ ${ }^{1}$ Bogor Agriculture Development Polytechnic (POLBANGTAN BOGOR), INDONESIA. \\ E-mail: dyah.gandasari@gmail.com \\ ${ }^{2}$ Faculty of Animal Science, JENDERAL SOEDIRMAN UNIVERSITY, INDONESIA. \\ E-mail: mochamad.sugiarto@unsoed.ac.id \\ ${ }^{3}$ Management Department, BINUS Business School Undergraduate Program, BINA NUSANTARA UNIVERSITY, \\ INDONESIA. E-mail: diena.dwidienawati@gmail.com \\ ${ }^{4}$ Department of Communication and Community Development, Faculty of Human Ecology, IPB University, \\ INDONESIA. E-mail: sarwititi@apps.ipb.ac.id \\ ${ }^{5}$ UNIVERSITAS MULTIMEDIA NUSANTARA, INDONESIA. E-mail: david.tjahjana@gmail.com
}

\begin{abstract}
This study aimed to analyze the relationship between beef cattle farmers' characteristics and the communication networks. The research location was a group of beef cattle farmers in Subang Regency, West Java Province and took place from May to December 2019. This was a quantitative research with Sari Mulya Mandiri and Bina Insani farmers groups as the research samples. The respondents were 30 beef cattle farmers. The data collected were processed by Sociometric Analysis, Analysis of Communication Network Structure, and Spearman Rank Correlation Test. The results showed that the farmer characteristics were significantly related to the communication networks for all information.
\end{abstract}

Keywords: farmer characteristics, global centrality, group communication, local centrality

JEL Classification: C1, L2 


\section{Introduction}

The problem in developing beef cattle farming is that an increase does not follow beef cattle farming growth on a farm scale. Besides, the increasing number of farmers was not accompanied by an increase in welfare. The business's added value is not optimal because the farmers' on-farm activities are relatively small, and the current farmer institutional development is inadequate.

Group development and strengthening group capacity are needed to improve the welfare of farmers. Group development aims to help farmers with learning and cooperation to improve their standards of living and interests. Meanwhile, strengthening group capacity aims to facilitate groups through a series of participatory activities to develop group institutions to become active, healthy, participatory, and beneficial for their members in improving the standards of living and welfare (P4K, 2001 in Suwardi, 2009).

The study (Suwardi, 2009) showed that the factors that influenced farming institutions' development are farmers' characteristics, the nature of innovation, supporting elements, and government policies. When the level of innovation in learning growth and the development of farmer economic institutions is right, mature group dynamics will develop into economic institutions. For this reason, research in the form of action studies to increase farmers' institutional capacity is needed, mainly farming institutions in ruminant (beef cattle/buffalos). This research is limited to analyzing the beef cattle farmers groups' diversity by exploring the relationship between the farmers' characteristics and the communication networks.

\section{Literature Review}

The study on the institutional development of beef cattle farmer groups refers to Lewin's 1948 action research concept and Monge \& Contractor (2003) communication networks and Rogers \& Kincaid's (1981) Convergence of Communication. Thus, the results of the study can theoretically be used to evaluate group communication networks.

Action research is the production of new knowledge through the search for solutions or improvements to real-life practical problem situations (Elden and Chisholm 1993 in Basuno et al., 2008), departing from a conceptual framework, developing, testing, and refining theories about aspects of the specific problem context (Basuno et al., 2008).

The term action research was first put forward by Lewin (1948). Lewin (1948) in Basuno et al. (2008) proposed the principle of a "spiral step" (cyclic), which consists of a circle of planning, action, and factfinding about the outcome of the action. The next step is a circle of planning, implementing, and finding facts to evaluate the results of the second step, and preparing the rationale for phase three, possibly modifying the overall plan.

Figure 1. Stages of the Action Review Process

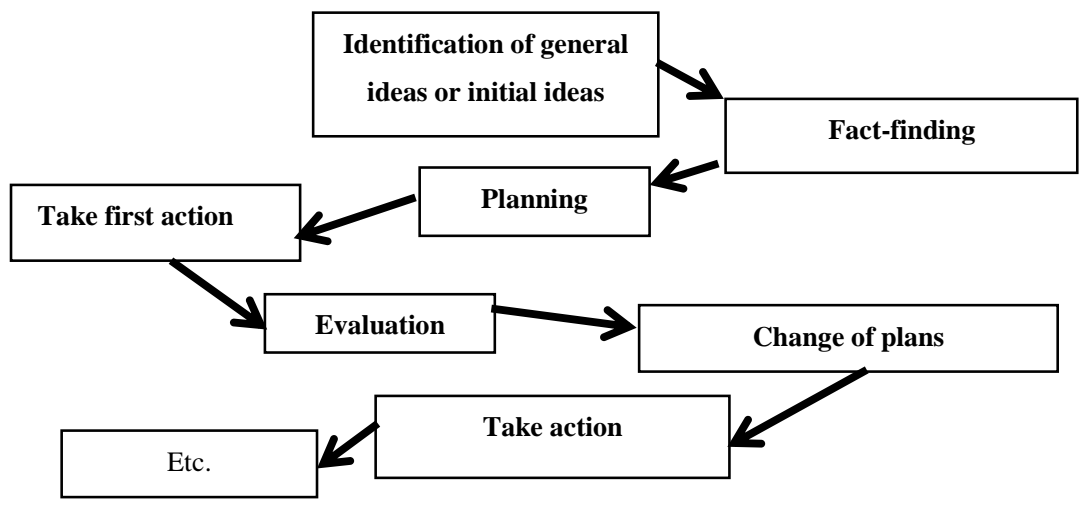

Source: Lewin (1948) in Basuno et al. (2008)

This research is an action research study for the development of farmer institutions as a socioeconomic forum where it takes approximately three years to implement, which consists of several 
stages, namely: (1) Study of Beef Cattle Farmer Groups (as a social forum), (2) Action / Actions on Group Institutions for Institutional Strengthening, (3) Institutional Studies for Beef Cattle Farmer Groups (as a social and economic forum), (4) Action / Actions on Group Institutions for Institutional Development as an economic forum and institutional development as a social fórum, (5) Study Beef Cattle Farmer Groups (as a social and economic forum), (6) Action / Actions on Group Institutions for institutional development as a social and economic forum. This research is limited to assessing the performance of the Beef Cattle Farmer Groups (first stage).

This study refers to the framework proposed by Rogers \& Kincaid (1981), in which individual characteristics are thought to be related to communication network variables. The relationship between farmers varies depending on personal characteristics. Individual characteristic variables are measured by age, level of education, number of livestock, farming experience, and land area.

Network indicators used in this study refer to measurements according to Freeman (1979) in Scot (2000), which consist of local centrality and global centrality. Local centrality is chosen because it can provide an overview of a person's ability to establish relationships with other individuals within the social system in the environment around him. Meanwhile, global centrality is chosen because it can describe a person's ability to access all individual members of the system as a whole. It is suspected that the higher the level of a farmer's ability to contact other individuals or other sources of information in the neighborhood system and the whole system, the better the agribusiness activities carried out by the farmer.

In analyzing the relationship between farmers' personal characteristics and the communication networks in beef cattle agribusiness, this study refers to the framework proposed by Rogers \& Kincaid (1981), as shown in Figure 2.

Figure 2. Relationship Framework for Personal Characteristics of Beef Cattle Farmers with Communication



The research hypothesis is proposed as follows: "There is a relationship between individual characteristics of beef cattle farmers and communication networks."

The relationship between farmers varies depending on individual characteristics. Individual characteristic variables are measured by age, education level, livestock, farming experience, and side jobs outside farming. Several previous studies that examined the relationship between individual characteristics and communication networks such as social and culture (Gustina et al., 2008), diffusion of innovation (Alim, 2013; Cindoswari, 2012; Rangkuti, 2007), and in a variety of agricultural commodities (Ellyta, 2006; Gandasari \& Musyadar, 2018, 2019; Raharjo et al., 2017; Saleh, 2006; Utami, 2013) exist, but a study on livestock agribusiness and particularly beef cattle commodity has not frequently been conducted.

\section{Metodology}

The research location was determined and limited to the farmers' group members of the Cinagarabogo SPR in Subang Regency. The area of this research is Cipunagara District, Subang Regency, West Java Province. The location selection was made with the active group's consideration and was located in the production center of beef cattle. The research took place from May - December 2019.

The sampling technique was purposive sampling, while the unit of analysis was individual beef cattle farmers. The respondents in this study used a census where the respondents in this study were 
taken from the entire population (farmer groups). This method was taken because this research is a communication network research that emphasizes the delineation of communication structures.

The samples of farmer groups for this research were Sari Mulya Mandiri, Tanjung Cibogo Village, and Bina Insani, Wanasari Village in Cipunagara District, Subang Regency. Sari Mulya Mandiri is a Beginner's farmer group with 12 members, while Bina Insani's is an Advanced group of farmers with 18 members. Total respondents in this study amounted to 30 beef cattle farmers.

The collected data were in the form of primary data and secondary data. Primary data were obtained through interviews with respondents using questionnaires and open interviews with several informants such as local government officials and local community. Interviews with informants can provide information related to local conditions and information that complements the research data according to the research objectives. Secondary data were obtained from literature studies, books, and reports from the Animal Husbandry Office of Subang Regency.

The instrument used in this study was a questionnaire. Interviews using a questionnaire were conducted to obtain information from respondents related to the research topic. Interviews using a questionnaire were completed by asking about the communication networks and personal characteristics of individual farmers.

Data collection regarding respondents' involvement in communication networks was carried out by asking sociometric questions, namely questions from whom a person gets certain information and to whom someone talks about that certain information. A sociogram can be formed through answers to existing sociometric questions to see communication patterns, information exchange flows, and the roles of individuals involved in communication networks (Rogers \& Kincaid, 1981). Questions about individual farmers' characteristics consist of age, education level, number of livestock, farming experience, and land area.

The data collected were processed by among others (1) Sociometric analysis. The sociometric analysis is used to see the communication networks that occur among farmers. The method is used to create a matrix that contains the relationship data first. Relationship data were obtained from sociometric questions in the questionnaires, (2) Analysis of the Communication Network Structure. The analysis of the communication network structure was analyzed using UCINET VI. The use of UCINET $\mathrm{VI}$ in this study is to calculate the value of local centrality and the value of global centrality, (3) To determine the relationship between the farmers' personal characteristics variables and the variables of the communication networks was carried out using the Spearman Rank correlation statistics. This correlation (Umar, 2005, Qureshi, Muhammad Imran, et al. 2020). assumes that the data consist of pairs of numerical or non-numerical observations. The Spearman Rank correlation formula used to analyze the relationship between variables from the ordinal scale data is as follows:

$$
r_{s}=\frac{6 \sum_{j=1}^{n} d i^{2}}{n\left(n^{2}-1\right)}
$$

$r_{s}=$ Spearman's rank correlation coefficient

$\mathrm{n}=$ data quantity

$d=$ the amount of difference between the rank for xi and yi

1 and $6=$ Constanta

$\mathrm{N}=$ number of pairs between variables

\section{Results and Findings}

\subsection{General Condition of Agriculture in Subang Regency}

The agricultural sector largely supports the economy in Subang Regency. Subang Regency has the third-largest rice field area in West Java after Indramayu and Karawang, and is the third-largest contributor to rice production in West Java. The rice field area in Subang Regency in 2016 was about 84,503 hectares. 
Some crop production has increased. For example, maize reached 513.53 tons in 2015, and increased to reaching 528.76 tons in 2016. Cassava has also increased, which amounted from $11,263.91$ tons in 2015 to $11,729.74$ tons in 2016.

Subang Regency also produces vegetables. The type of vegetable that is mostly grown is chili, which reached 2,882 tons in 2016. Many kinds of fruits are also made from Subang Regency, one of which is banana production, which got 2,279,779 tons in 2016, followed by pineapple production of $95,266.34$ tons, and mango, amounting to 2,279,799 tons (BPS Subang, 2019).

Several plantation commodities whose production is relatively large include rubber, coconut, oil palm, coffee, and pepper. Meanwhile, large plantations managed by PT Perkebunan Nusantara VIII have Jalupang, Tambaksari, Wangunreja, and Ciater Gardens, as well as a sugar factory located in Purwadadi sub-district (BPS Subang, 2019).

The livestock population in 2016 consisted of 1,086 dairy cows, 33,232 beef cattle, 2,940 buffalos, 303 horses, 27,445 goats, and 254,891 sheep. Meanwhile, for poultry in 2016, according to data from the District Livestock Service Office Subang, there were 1,319,001 native chickens, 61,900 layer chickens, 47,756,220 broilers, and 542,203 ducks (BPS Subang, 2019).

\subsection{Beef Catlle Development Program in Subang Regency}

Animal husbandry development is a part of economic developments developed in Subang Regency, which aims to increase the income, welfare, standard of living, and independence of livestock farmers and food sufficiency with continuous efforts through the application of integrated agribusiness. Like other economic sectors, the livestock sub-sector is required to continue to grow and increase its productivity in line with the dynamics of an ever-growing society.

Since the issuance of Regulation of the Minister of Agriculture Number 50 of 2012 concerning Guidelines for the Development of Agricultural Areas to support Law Number 41 of 2009 concerning the Protection of Sustainable Food Agricultural Land (PLP2B), the Central and Regional Governments strive to realize these regulations following the conditions of their respective regions by building areabased livestock.

The year 2016 is the starting point for the revival of farmers to become sovereign by coordinating the consolidation of small farmers, which begins with establishing a Center of Smallholder Livestock (SPR). The SPR was built starting from the philosophy that the development of animal husbandry and health can only be obtained when the government and the parties make various efforts that pay attention to the principles of one management, organization, and empowerment of farmers realizing a planned livestock population. SPR is a forum for transferring knowledge to create awareness to collaborate and improve farming skills properly.

The beef cattle development policy in Subang Regency is planned to have five areas: Kasaliang, Cinagarabogo, Jalansagalapanjang, Pandey, and Cupukada. However, from natural resources, institutions and supporting infrastructure that are considered ready to be formed into SPR, namely the Kasaliang, Cinagarabogo, and Jalansagalapanjang areas. Due to budget constraints, those who received support from the 2016 APBN-TP could only facilitate 2 Pioneer SPRs, namely, 1). Kasabian SPR, with covers Kasomalang, Cisalak, and Tanjungsiang Districts, and 2). SPR Cinagarabogo which covers Cipunagara and Cibogo Districts.

\subsection{Development of SPR Cinagarabogo into a Corporate Management Unit for Beef Cattle Farmers}

The Centre for Smallholder Livestock (SPR) Cinagara Bogo is an SPR formed to become a collective business center for integrated beef cattle farming in the Cipunagara and Cibolo areas. This SPR consists of 20 farmer groups with total household-scale ownership. The problem with SPR Cinagara Bogo is that the existing farmers' institutional development is inadequate. 
In 2018, the Minister of Agriculture Regulation was issued regarding the Development of Corporatebased Agricultural Areas. The district government followed up by forming the Farmer Corporation Area Development Management Unit.

\subsection{Profile of Respondents}

The characteristics of smallholder farmers included: (1) age, (2) education, (3) farm-scale, (4) number of livestock, (5) experience in farming, and (6) land area.

\subsubsection{Age of Farmers}

Age is the length of time the respondents lives from birth to the time the research was conducted, which is stated in years. The farmers' age is closely related to a person's physical abilities in business activities, business experience, and making decisions about an activity that concerns him. In detail, the age categories of farmers can be seen in Figure 3.

Figure 3. Age of Beef Cattle Farmers

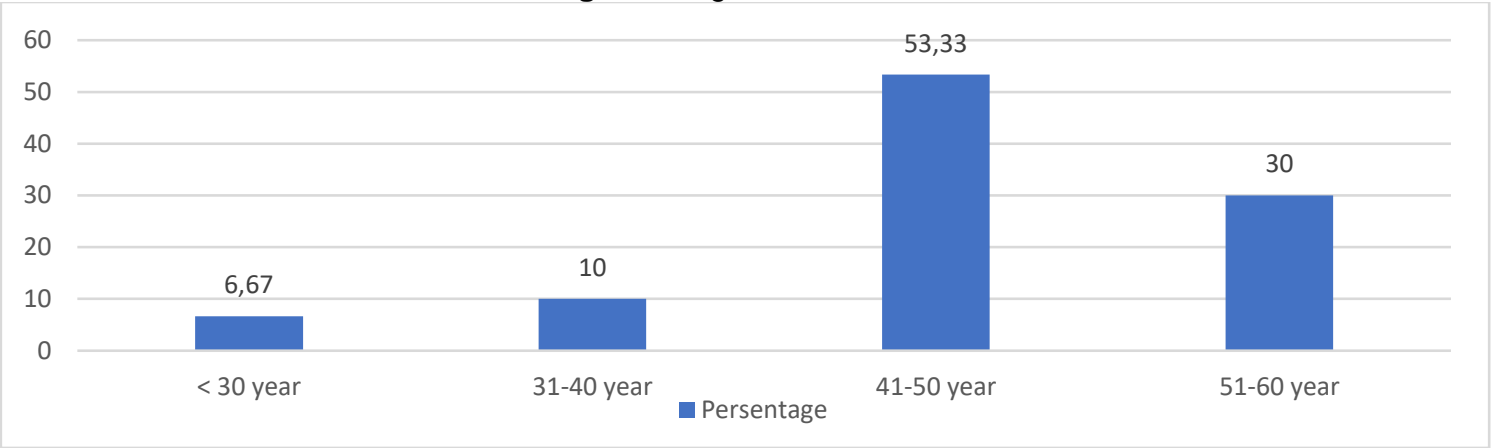

Figure 3 shows that majority of the respondent (53.33\%) was at the age of $41-50$ years. This fact indicates that the opportunity for farmers to carry out their business is optimal because it can give hope of working better to improve their welfare. A control span for the productive age of group members between 30-60 years will facilitate the learning process to strengthen group capacity. According to the Department of Agriculture in the P4K Project (2001), small farmers who participate in the group learning program are of productive age or less than 60 years (Suwardi, 2009).

\subsubsection{Farmers' Formal Education Level}

The level of formal education is an indicator to determine a person's thinking ability. The higher a person's education, the easier it will be for people to understand the various information and innovations-broader knowledge and insight, more rational in making decisions, and more assertive in dealing with something. The level of formal education of the respondent farmers is shown in Figure 4.

Figure 4. The Educational Level of Beef Cattle Farmers

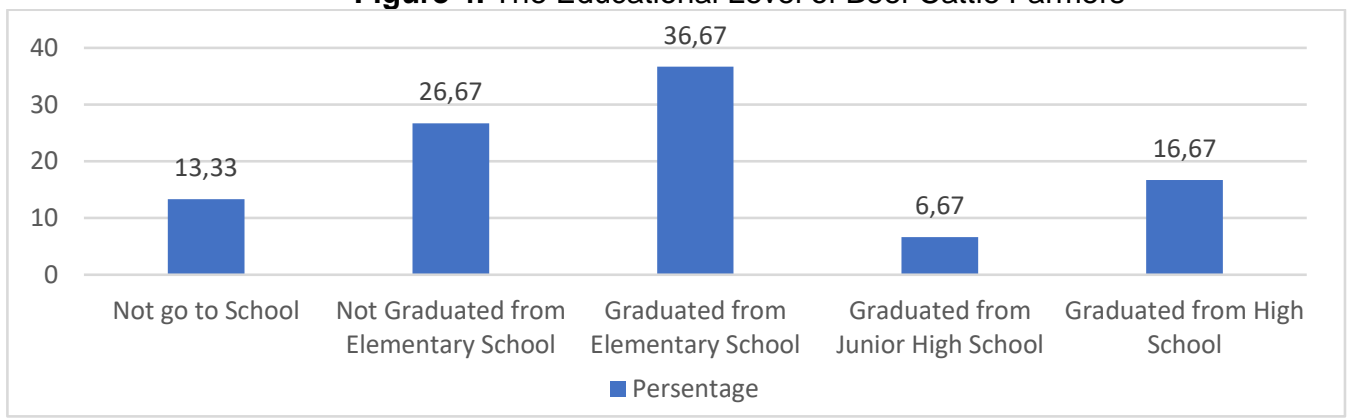

Figure 4 shows that the average level of education of respondents who graduated from elementary school is $36.67 \%$. There are still some respondents who do not go to school and have graduated from elementary school. An increase in group status is not balanced by the rise in formal education, 
indicating that the integration of mentoring programs with the Ministry of National Education is not optimal, especially those related to Pursuing Packages A, B, and C.

The level of formal education affects the respondents' attitude in deciding to make reforms. Following Pringgosaputro (1986) opinion in Suwardi (2009), the level of formal education affects how to respond and act in decision-making for his progress. Education is the most effective way to change people. Thus, education can make a real contribution to increasing knowledge.

\subsubsection{Farm Scale}

Farm scale is the number of livestock kept for beef cattle commodity farming. Figure 5 shows that most farmers (90\%) own between 10-15 heads. Generally, they carry out breeding type, which has a long income cycle.

Figure 5. Farm Scale of Beef Cattle



This fact illustrates that their business has led to economies of scale. The study (Dwijayanti et al., 2016) demonstrates that the level of break-even point for beef cattle farming is 1.9 Animal Unit, equivalent to 1 female seven calves, or one female and three calves.

\subsubsection{Beef Cattle Farming Experience}

Farming experience is the length of time the respondent has been a beef cattle farmer, from the first time he became a farmer until the research interview was conducted. Figure 6 shows that most of the respondents (80\%) have been farmers for more than 27 years. This fact indicates that the level of experience in breeding livestock is in the excellent category, and generally, this business has been carried out from generation to generation. Experience affects the level of respondent adoption of the group capacity building program. Experience is one way of knowing that a person is experienced in an indefinite period.

Figure 6. Farming Experience of Beef Cattle Farmers



Psychologically, all human thinking, personality, and temperament are determined by sense experience. Thoughts and feelings are not the causes of the behavior, but the action is caused by the past behavior (Rakhmat, 2005). Someone who works in a particular field for a relatively long time will gain more experience. 
Experience in the form of expertise is coupled with more learning; the higher the knowledge gained, and this will increase decision-making sensitivity. Walker (1973) argues that experience is the result of the accumulation of a person's natural processes, which influence the response he receives to decide what he receives.

A person's tendency to act depends on his experience because that experience determines the interests and needs he feels. From the observations of the respondents, it can be concluded that in the future, the experience of breeders needs to be used as the essential capital in smoothing the group capacity strengthening program.

\subsubsection{Land Area}

Respondents' land ownership varies from landless to ownership of less than one hectare. The average respondents, namely $48.27 \%$, have agricultural land between 0.1 and 0.5 ha. Meanwhile, based on the category of landless to ownership of less than one hectare, the number of respondents was $96.39 \%$.

\subsection{Analysis of the Relationship between Personal Characteristics and Farmer Communication Networks}

This study examines the relationship between farmer personal characteristics and communication networks. The test used is the Spearman correlation test. The Spearman correlation test is caused because the variables of the farmers' characteristics and the communication networks are ordinal data. The variables for farmers' characteristics are age, education, business scale, business length, and land area. The variables tested on the communication networks are local centrality and global centrality.

This study examines the relationship between personal characteristics, including age, education, farm-scale, livestock farming experience, and land area, with communication networks, namely local centrality and global centrality (Tables 1,2,3 and 4).

Table 1. Relationship between Farmer Personal Characteristics and Farmer Communication Network (Local Centrality) in Bina Insani

\begin{tabular}{|l|c|c|c|c|c|c|c|c|c|c|}
\hline \multirow{2}{*}{$\begin{array}{l}\text { Farmers' } \\
\text { personal } \\
\text { characteristi } \\
\text { cs }\end{array}$} & \multicolumn{6}{|c|}{$\begin{array}{c}\text { Cultivation } \\
\text { Information }\end{array}$} & $\begin{array}{c}\text { Breeding } \\
\text { Information }\end{array}$ & \multicolumn{2}{c|}{$\begin{array}{c}\text { Institutional } \\
\text { Information }\end{array}$} & \multicolumn{2}{c|}{$\begin{array}{c}\text { Marketing } \\
\text { Information }\end{array}$} & \multicolumn{2}{c|}{$\begin{array}{c}\text { Health } \\
\text { Information }\end{array}$} \\
\cline { 2 - 11 } & $\begin{array}{c}\text { In } \\
\text { Degree }\end{array}$ & $\begin{array}{c}\text { Out } \\
\text { Degree }\end{array}$ & $\begin{array}{c}\text { In } \\
\text { Degree }\end{array}$ & $\begin{array}{c}\text { Out } \\
\text { Degree }\end{array}$ & $\begin{array}{c}\text { In } \\
\text { Degree }\end{array}$ & $\begin{array}{c}\text { Out } \\
\text { Degree }\end{array}$ & $\begin{array}{c}\text { In } \\
\text { Degree }\end{array}$ & $\begin{array}{c}\text { Out } \\
\text { Degree } \\
\text { Degree }\end{array}$ & $\begin{array}{c}\text { In } \\
\text { Degree }\end{array}$ \\
\hline Age & -0.316 & -0.328 & -0.306 & -0.308 & $-.540^{*}$ & -0.271 & -0.447 & -0.301 & $-.470^{*}$ & -0.319 \\
\hline Education & 0.222 & 0.206 & 0.166 & 0.148 & 0.039 & 0.37 & 0.314 & 0.143 & -0.023 & 0.154 \\
\hline Farm scale & 0.245 & 0.001 & 0.349 & 0.093 & 0.454 & -0.087 & 0.229 & 0.131 & $\mathbf{. 5 9 8 * *}$ & 0.014 \\
\hline $\begin{array}{l}\text { Farming } \\
\text { experience }\end{array}$ & -0.316 & -0.042 & -0.047 & 0.003 & -0.154 & -0.101 & 0.099 & 0.019 & -0.007 & -0.029 \\
\hline Land area & 0.34 & $\mathbf{. 9 5 0 * *}$ & 0.432 & $\mathbf{. 9 4 3 * *}$ & -0.064 & $\mathbf{. 8 5 5 * *}$ & 0.176 & $\mathbf{. 9 2 8 * *}$ & 0.094 & $\mathbf{. 9 5 6 * *}$ \\
\hline
\end{tabular}

Remark ${ }^{*}$ significantly correlated at $p<0.05$ and ${ }^{* *}$ very significantly correlated at $p<0.01$ 
Table 2. Relationship between Farmer Personal Characteristics and Farmer Communication Network (Global Centrality) in Bina Insani

\begin{tabular}{|c|c|c|c|c|c|c|c|c|c|c|}
\hline \multirow{3}{*}{$\begin{array}{l}\text { Farmers' } \\
\text { personal } \\
\text { characteristics }\end{array}$} & \multicolumn{10}{|c|}{ Global Centrality Communication Network Bina Insani Farmer Group } \\
\hline & \multicolumn{2}{|c|}{$\begin{array}{l}\text { Cultivation } \\
\text { Information }\end{array}$} & \multicolumn{2}{|c|}{$\begin{array}{l}\text { Breeding } \\
\text { Information }\end{array}$} & \multicolumn{2}{|c|}{$\begin{array}{l}\text { Institutional } \\
\text { Information }\end{array}$} & \multicolumn{2}{|c|}{$\begin{array}{l}\text { Marketing } \\
\text { Information }\end{array}$} & \multicolumn{2}{|c|}{$\begin{array}{c}\text { Health } \\
\text { Information }\end{array}$} \\
\hline & Out Close & In Close & Out Close & In Close & Out Close & In Close & Out Close & In Close & Out Close & In Close \\
\hline Age & -0.039 & 0.328 & -0.196 & 0.192 & 0.423 & 0.271 & -0.139 & 0.302 & 0.355 & .a \\
\hline Education & -0.138 & -0.206 & 0.364 & -0.087 & -0.016 & -0.37 & -0.007 & -0.144 & 0.117 &.$a$ \\
\hline Farm scale & -0.272 & 0 & 0.043 & -0.378 & $-.548 *$ & 0.087 & -0.112 & -0.123 & $-.620 * *$ & .a \\
\hline $\begin{array}{l}\text { Farming } \\
\text { experience }\end{array}$ & -0.178 & 0.042 & -0.158 & -0.13 & 0.013 & 0.101 & -0.25 & -0.016 & -0.018 & .a \\
\hline Land area & 0.452 & $-.950 * *$ & -0.03 & $-.661 * *$ & 0.225 & $-.855^{* *}$ & 0.099 & $-.932 * *$ & -0.05 & .a \\
\hline
\end{tabular}

Remark $^{*}$ significantly correlated at $p<0.05$ and ${ }^{* *}$ very significantly correlated at $p<0.01$

Table 3. Relationship between Farmer Personal Characteristics and Farmer Communication Network (Local Centrality) in Sarimulya Mandiri

\begin{tabular}{|c|c|c|c|c|c|c|c|c|c|c|}
\hline \multirow[b]{3}{*}{$\begin{array}{l}\text { Farmers' personal } \\
\text { characteristics }\end{array}$} & \multicolumn{10}{|c|}{ Local Centrality Communication Network Sarimulya Mandiri Farmer Group } \\
\hline & \multicolumn{2}{|c|}{$\begin{array}{l}\text { Cultivation } \\
\text { Information }\end{array}$} & \multicolumn{2}{|c|}{$\begin{array}{l}\text { Breeding } \\
\text { Information }\end{array}$} & \multicolumn{2}{|c|}{$\begin{array}{l}\text { Institutional } \\
\text { Information }\end{array}$} & \multicolumn{2}{|c|}{$\begin{array}{l}\text { Marketing } \\
\text { Information }\end{array}$} & \multicolumn{2}{|c|}{$\begin{array}{c}\text { Health } \\
\text { Information }\end{array}$} \\
\hline & $\begin{array}{l}\text { Out } \\
\text { Degree }\end{array}$ & $\begin{array}{c}\text { In } \\
\text { Degree }\end{array}$ & $\begin{array}{l}\text { Out } \\
\text { Degree }\end{array}$ & $\begin{array}{l}\text { In } \\
\text { Degree }\end{array}$ & $\begin{array}{l}\text { Out } \\
\text { Degree }\end{array}$ & $\begin{array}{c}\text { In } \\
\text { Degree }\end{array}$ & $\begin{array}{l}\text { Out } \\
\text { Degree }\end{array}$ & $\begin{array}{c}\text { In } \\
\text { Degree }\end{array}$ & $\begin{array}{l}\text { Out } \\
\text { Degree }\end{array}$ & $\begin{array}{c}\text { In } \\
\text { Degree }\end{array}$ \\
\hline Age & -0.223 & 0.096 & -0.091 & 0.081 & 0.066 & 0.081 & -0.294 &.$a$ & -0.066 & .a \\
\hline Education & 0.417 & 0.292 & 0.426 & 0.321 & 0.332 & 0.321 & $.824 * *$ &.$a$ & $.612 *$ & .a \\
\hline Farm scale & $.853^{* *}$ & $.980 * *$ & $.934 * *$ & $.952 * *$ & $.954^{* *}$ & $.952 * *$ & 0.222 &.$a$ & $.736 * *$ & .a \\
\hline Farming experience & $.919 * *$ & $.990 * *$ & $.981 * *$ & $1.000 * *$ & $.991 * *$ & $1.000 * *$ & 0.234 &.$a$ & $.818^{* *}$ & .a \\
\hline Land area & $.911 * *$ & $.989 * *$ & $.977^{* *}$ & $.999 * *$ & $.989 * *$ & $.999 * *$ & 0.229 & .a & $.823 * *$ & .a \\
\hline
\end{tabular}

Remark $^{*}$ significantly correlated at $p<0.05$ and ${ }^{* *}$ very significantly correlated at $p<0.01$

Table 4. Relationship between Farmer Personal Characteristics and Farmer Communication Network (Global Centrality) in Sarimulya Mandiri

\begin{tabular}{|c|c|c|c|c|c|c|c|c|c|c|}
\hline \multirow{3}{*}{$\begin{array}{l}\text { Farmers' } \\
\text { personal } \\
\text { characteristics }\end{array}$} & \multicolumn{10}{|c|}{ Global Centrality Communication Network Sarimulya Mandiri Farmer Group } \\
\hline & \multicolumn{2}{|c|}{$\begin{array}{l}\text { Cultivation } \\
\text { Information }\end{array}$} & \multicolumn{2}{|c|}{$\begin{array}{l}\text { Breeding } \\
\text { Information }\end{array}$} & \multicolumn{2}{|c|}{$\begin{array}{l}\text { Institutional } \\
\text { Information }\end{array}$} & \multicolumn{2}{|c|}{$\begin{array}{l}\text { Marketing } \\
\text { Information }\end{array}$} & \multicolumn{2}{|c|}{$\begin{array}{c}\text { Health } \\
\text { Information }\end{array}$} \\
\hline & $\begin{array}{l}\text { Out } \\
\text { Close }\end{array}$ & $\begin{array}{l}\text { In } \\
\text { Close }\end{array}$ & $\begin{array}{l}\text { Out } \\
\text { Close }\end{array}$ & $\begin{array}{l}\text { In } \\
\text { Close }\end{array}$ & $\begin{array}{l}\text { Out } \\
\text { Close }\end{array}$ & $\begin{array}{l}\text { In } \\
\text { Close }\end{array}$ & $\begin{array}{l}\text { Out } \\
\text { Close }\end{array}$ & $\begin{array}{l}\text { In } \\
\text { Close }\end{array}$ & $\begin{array}{l}\text { Out } \\
\text { Close }\end{array}$ & $\begin{array}{l}\text { In } \\
\text { Close }\end{array}$ \\
\hline Age & $.641 *$ & $-.667^{*}$ & 0.502 & -0.492 & -0.044 & 0.034 & 0.294 & .a & 0.149 &.$a$ \\
\hline Education & -0.41 & 0.309 & $-.617^{*}$ & $.590 *$ & -0.193 & 0.108 & $-.824 * *$ & .a & $-.625^{*}$ &.$a$ \\
\hline Farm scale & -0.282 & -0.043 & -0.299 & 0.172 & -0.421 & 0.171 & -0.222 & .a & $-.734 * *$ & .a \\
\hline $\begin{array}{l}\text { Farming } \\
\text { experience }\end{array}$ & -0.21 & -0.122 & -0.384 & 0.26 & -0.295 & 0.022 & -0.234 & .a & $-.817 * *$ & . a \\
\hline Land area & -0.194 & -0.137 & -0.374 & 0.251 & -0.283 & 0.009 & -0.229 & .a & $-.824 * *$ & .a \\
\hline
\end{tabular}




\subsubsection{Bina Insani Farmer Group}

\subsubsection{Age of farmers}

Based on Table 1 and Table 2, the Spearman correlation test results show a relationship between the age of the beef cattle farmers, the farm-scale, and the area of land for livestock farming with the farmers' communication networks. Age is significantly and negatively related to global centrality with a value of $r=-0.540 *$ Institutional and $r=-0.470 *$ Animal health. This means that the older the farmers are, the less often they seek information on institutional and livestock health. In other words, the younger the farmers, the more active they are in seeking information on institutional and livestock health.

This is in line with Utami (2013) and Gandasari \& Musyadar (2019) findings on vegetable commodities. Vegetable commodities require relatively young people who have a relatively high innovation level (Gandasari \& Musyadar, 2019; Utami, 2013). Based on the theory of Lionberger and Gwin (1982), it is stated that the older a person is, the slower he is in adopting innovation, and tends only to carry out routine activities that are implemented by those around him. Research on farmer profiles, namely age, is related to efforts to obtain information in line with research results Gandasari \& Musyadar (2019), Utami (2013), Sulistiawati (2014), Aziz (2002), Shiddieqy (2001).

\subsubsection{Farm Scale}

The farm scale has a significant and positive relationship with the local centrality of livestock health with a value of $r=0.598^{* *}$, a significant and negative association with the global centrality of institutions with a value of $r=-0.548 *$, and a very significant and negative relationship with the global centrality of livestock health with a value of $r=-0,620^{* *}$. This means that the larger the farm scale, the more communication networks are needed and formed, and the easier it will be to find or get information about institutional and livestock health.

\subsubsection{Land Area}

Land area has a very significant and positive relationship with local centrality with a value of $r=$ $0.950^{* *}$ (indegree cultivation), $r=0.943^{* *}$ (nursery indegree), $r=0.855^{* *}$ (institutional indegree), $r$ $=0.928 * *$ (marketing indegree) ), $r=0.956 * *$ (livestock health index) and has a very significant and negative relationship to global centrality with a value of $r=-0.950 * *$ (out close cultivation), $r=-0.661$ ** (nursery out close), $r=-0.855 * *$ (institutional out close), $r=-0.932 * *$ (marketing out close). This means that the wider the land ownership or the more land area that can be accessed by breeders, the more information they have because they are active in seeking or obtaining information from outside to reduce uncertainty in beef cattle agribusiness.

The land is one of the essential factors of production in farming development. Limited land availability has an impact on farming development and farmers' income. The research results on the land area are related to obtaining information (Aziz, 2002; Gandasari \& Musyadar, 2019; Raharjo et al., 2017; Shiddieqy, 2001; Sulistiawati, 2014; Utami, 2013).

\subsubsection{Sarimulya Mandiri Farmer Group}

\subsubsection{Age of Farmers}

Based on Table 3 and Table 4, the Spearman correlation test results show that there is a relationship between the age of the farmers, farmer education, farm-scale, length of farming, and the area of livestock farming with the breeders' communication networks. Age was significantly and positively related to global centrality with a value of $r=0.641 *$ Cultivation (out close) and significantly and negatively associated with $r=-0.667 *$ Cultivation (inclose). This means that the older the farmers are, the less active they are looking for information from outside, only looking for information around them. The younger the farmers are, the more engaged they are in seeking out information on breeding 
(cosmopolitan). This is in line with the findings of Gandasari \& Musyadar (2019), Utami (2013), Sulistiawati (2014), Shiddieqy (2001), and Aziz (2002), which state there is a relationship between age and communication networks.

\subsubsection{Education of Farmers}

Education has a very significant and positive relationship with local marketing centrality with a value of $r=0.824 * *$, livestock health with a value of $r=0.612 * *$, a significant and negative relationship with global centrality of nurseries with a value of $r=-0.617^{*}$ (out close) $R=0.590 *$ (inclose), a very significant and negative relationship to global marketing centrality with a value of $r=-0.824 * *$, and livestock health with a value of $r=-0.625^{* *}$. This means that the higher the farmers' education level, the more often they are in seeking information about marketing and livestock health.

\subsubsection{Farm Scale}

Farm scale has a very significant and positive relationship with beef cattle agribusiness's local centrality with a value of $r=0.736^{* *}$ to $0.980^{* *}$. This means that the larger the farm scale, the more communication networks are needed and formed, and the easier it will be to find or get information about institutional and livestock health.

\subsubsection{Beef Cattle Farming Experience}

The length of time to work for livestock has a very significant and positive relationship with beef cattle agribusiness's local centrality with a value of $r=0.818^{* *}$ to $1,000 * *$. This means that the more time spent working on livestock, the more communication networks will be formed, and the easier it will be to find or get information about beef cattle agribusiness.

\subsubsection{Land Area}

The land area has a very significant and positive relationship with local centrality with $r=0.823 * *$ to $0.999^{* *}$. It has a very significant and negative relationship with global centrality with a value of $r=$ $-0.824 * *$ (animal health out close). This means that the wider the land ownership or the more land can be accessed by breeders, the more information they have because they are active in seeking or obtaining information from outside to reduce uncertainty in beef cattle agribusiness. Several findings regarding land area are related to obtaining information (Aziz, 2002; Gandasari \& Musyadar, 2019; Rahardjo, 2016; Shiddieqy, 2001; Sulistiawati, 2014).

The performance-based on the communication structure in Bina Insani and Sarimulya Mandiri farmer groups shows that farmer characteristics are significantly related to the communication networks on all information. This is in line with the findings of Gandasari, Suwardi, et al. (2020) and Gandasari, Sugandi, et al. (2020), where the information exchange network between farmers in one group is still low. However, a structure of information exchange between farmers and between farmers- SPR has been formed. Most of the beef cattle farmers have communicated with the head or SPR management. This means that a network structure has been built in the farmers' group and between farmers' group-SPR, although it is still insufficient. This means that there is still a need to strengthen institutional functions through joint activities and regular interactions in meeting everyday needs to improve farmers' welfare and develop farmer institutions into strong and competitive farmer economic institutions. Group as an organization has to provide the room for the involvement of all organization components (Fensi, 2018), and communication among the members of group will affect the cohesiveness of the group (Iskandar \& Syueb, 2018). 


\section{Conclusion}

The performance-based on the communication structure in Bina Insani and Sarimulya Mandiri farmer groups shows that farmer characteristics are significantly related to the communication networks on all information.

Some suggestions for farmers' institutional development are: (1) to immediately optimize action plans that involve stakeholders in strengthening institutional functions through joint activities and regular interactions in meeting mutual needs; and (2) the role of the Subang Regency Government in facilitating the development of farmer economic institutions will significantly determine the success of the development of farmer economic institutions.

The correlation model, which is built on empirical and theoretical studies of the correlation between the structure of the communication networks and the farmers' characteristics, can be used as an initial model for the follow-up study stages, particularly in empowering farmers in developing institutions. Another study that is needed is about a causality model that is built on empirical and theoretical studies of the causal relationship between the factors that influence the adoption rate of farmer economic institutional development consisting of farmer characteristics, nature of innovation, supporting elements, and government policies in Subang Regency.

\section{Acknowledgement}

We thank Dr Siswoyo and Dr Dayat and the Polbangtan Bogor for their support. We thank to Universitas Multimedia Nusantara for their partially funding support.

\section{References}

1. Alim, S. (2013). Studi Jaringan Komonikasi Dalam Penerapan Higien dan Sanitasi Pemerahan Pada Kelompok Peternak Sapi Perah. Institut Pertanian Bogor.

2. Aziz, A. (2002). Analisis jaringan komunikasi dalam masyarakat tradisional kampung naga (Kasus dalam usahatani padi). Institut Pertanian Bogor.

3. Basuno, E., Iqbal, M., Suhaeti, R., \& Budhi, G. (2008). Kaji Tindak (Action Research) Pemberdayaan Masyarakat Pertanian Wilayah Tertinggal. Pusat Analisis Ekonomi dan Kebijakan Pertanian.

4. Bps Subang. (2019). Subang Dalam Angka 2019. In Badan Pusat Statistik Kabupaten Subang.

5. Cindoswari, A. R. (2012). Jaringan Komunikasi Dalam Penerapan Teknologi Produksi Ubi Kayu (Kasus Petani Ubi Kayu Di Desa Suko Binangun, Kecamatan Way Seputih, Kabupaten Lampung Tengah, Provinsi Lampung). Institut Pertanian Bogor.

6. Dwijayanti, M., Paturochman, M., \& Firman, A. (2016). Analisis Titik Impas Dan Efisiensi Usaha Pembibitan Sapi Potong di Desa Sindanglaya, Kecamatan Tanjungsiang, Kabupaten Subang. Student E-Journal UNPAD, 5(3).

7. Ellyta. (2006). Analisis Jaringan Komunikasi Petani dalam Pemasaran Lidah Buaya. Institut Pertanian Bogor.

8. Fensi, F. (2018). Urgensi Komunikasi dalam Pengembangan Organisasi Modern. Ultimacomm, 9(1), 59-68.

9. Gandasari, D., \& Musyadar, A. (2018). Price and Marketing Information in Chili Farmers Communications Network in Indonesia. International Journal of Engineering \& Technology, 10511054. www.sciencepubco.com/index.php/IJET

10.Gandasari, D., \& Musyadar, A. (2019). The Relationship of Farmers' Personal Characteristics and Communication Networks among Chili Farmers in Collecting Price Information and Marketing. International Journal of Advanced Science and Technology, 28(8s), 582-590.

11.Gandasari, D., Sugandi, A., Wihansah, R. R. S., Wardani, \& Suwardi, S. (2020). Sociometry analysis of beef cattle farmers institution in Indonesia: Case of bina insani as an advanced farmers group. International Journal of Advanced Science and Technology, 29(3), 5375-5385.

12.Gandasari, D., Suwardi, S., Wihansah, R., Wardani, \& Taopik, O. (2020). Analysis of agribusiness 
communication network among beef cattle farmers: Case study at sarimulya mandiri as the beginner's farmers group. International Journal of Advanced Science and Technology, 29(3), 53395347.

13.Gustina, A., Hubeis, A., \& Riyanto, S. (2008). Jaringan Komunikasi Dan Peran Perempuan Dalam Mempertahankan Budaya Rudat (Studi Pada Masyarakat Desa Negeri Katon, Kecamatan Negeri Katon, Lampung Selatan). Jurnal Komunikasi Pembangunan, 6(1), 246051.

14.Iskandar, J., \& Syueb, S. (2018). Pengaruh Komunikasi Interpersonal dan Komunikasi Kelompok terhadap Kohesivitas Kelompok pada Supporter Persebaya Korwil Suramadu. Jurnal ULTIMA Comm, 9(2), 90-109.

15.Monge, P., \& Contractor, N. (2003). Theories of Communication Networks. Oxford University Press.

16.Qureshi, Muhammad Imran, et al. "Classifications of sustainable manufacturing practices in ASEAN region: A systematic review and bibliometric analysis of the past decade of research." Sustainability 12.21 (2020): 8950.

17.Rahardjo, A. (2016). Jaringan komunikasi pemasaran kakao di kecamatan anreapi kabupaten polewali mandar, provinsi sulawesi barat agus raharjo. Institut Pertanian Bogor.

18.Raharjo, A., Muljono, P., \& Matindas, K. (2017). Jaringan Komunikasi Pemasaran Kakao Di Kecamatan Anreapi, Kabupaten Polewali Mandar, Provinsi Sulawesi Barat. Jurnal Komunikasi Pembangunan, 15(1), 1-14.

19. Rakhmat, J. (2005). Psikologi Komunikasi. Remaja Rosdakarya.

20.Rangkuti, P. A. (2007). Jaringan komunikasi petani dalam adopsi inovasi teknologi pertanian. Institut Pertanian Bogor.

21.Rogers, E. M., \& Kincaid, D. L. (1981). Communication Networks: Toward a New Paradigm for Research. London: The Free Press.

22.Saleh, A. (2006). Tingkat Penggunaan Media Massa dan Peran Komunikasi Anggota Kelompok Peternak dalam Jaringan Komunikasi Penyuluhan Sapi Potong. Media Peternakan, 29(2), 107-120.

23.Scot, J. (2000). Social network analysis. SAGE Publications.

24.Shiddieqy, M. (2001). Perilaku Komunikasi Anggota Kelompok Tani Penghijauan dalam Beradaptasi terhadap Sistem Pemberian Dana Langsung. Institute Pertanian Bogor.

25.Sulistiawati, A. (2014). Analisis Jaringan Komunikasi dan Evaluasi Jaringan Kepemimpinan dalam Gabungan Kelompok Tani (Studi Kasus di Desa Lalaldon, Kecamatan Ciomas, Kabupaten Bogor, Provinsi Jawa Barat).

26.Suwardi, S. (2009). Faktor-faktor yang Mempengaruhi Adopsi Penguatan Kapasitas Kelompok serta Dampaknya terhadap Dinamika Kelompok Tani (Kasus Program Peningkatan Pendapatan Petani Kecil di Kabupaten Sumedang). Universitas Padjadjaran.

27.Umar, H. (2005). Riset Pemasaran \& Perilaku Konsumen. Penerbit PT Gramedia Pustaka Utama.

28.Utami, D. (2013). Jaringan Komunikasi Informasi Harga dan Pemasaran Sayur. Institut Pertanian Bogor.

29.Walker, W. (1973). Conditioning and Instrumental Learning (Vol. 15). UI-Press. internalpdf://72.120.20.1/walker 1973.pdf 